\title{
DIE CHRISTUSPREDIKING VAN DIE OU TESTAMENT
}

Prof. J. A. Loader (Unisa)

Wanneer ons ons aan hierdie geweldige onderwerp waag, is daar teoreties verskillende maniere waarop ons te werk kan gaan. Ons sou in die kerklike tradisie kon nagaan watter gedeeltes van die $\mathrm{Ou}$ Testament gewoonlik as Christusprediking opgevat is en vervolgens ' $n$ eksegetiese toetsing van die tradisionele menings kon onderneem. Ons sou ook dié gedeeltes van die Ou Testament wat in die Nuwe Testament as messiaanse profesieë beskou word, kon ondersoek om vas te stel watter ooreenkomste en verskille daar tussen die ouer vorm van die tradisie en die vroeg-kerklike interpretasie daarvan bestaan. Of ons sou kon redeneer dat die woord "Christus" dieselfde is as mešiah en dat alleen dié gedeeltes waar die woord uitdruklik voorkom, vir 'n beskrywing van die Christusprediking in die Ou Testament kwalifiseer - wat ons sal uitbring by die koningsteologie. Ten slotte sou ons ook kon probeer vasstel wat die oorsprong van die messiaanse teologie is en die geskiedenis van sy oorlewering kon beskryf.

Hierdie metodes is almal histories-deskriptief. Hoewel hulle almal kan bydra tot die verheldering van die veld, geraak nie een tot 'n diepere teologiese ondersoek van die probleme op hierdie terrein nie. Die vraag vir ons is immers nie alleen of ons iets weet van 'n messiaanse opvatting wat ou Israel gehuldig het nie, maar of die Ou Testament vir ons 'n Christusboodskap bring. Daarom sal ons nou eers ' $n$ voëlvlug oor die Ou-Testamentiese messiasvoorstelling neem en daarna die kort oriëntering gebruik om ons te verantwoord oor die teologiese problematiek van ons onderwerp.

Soos welbekend, is die term „Christus" die vergrieksing van die Hebreeuse woord mesiah of messias, soos ons geleer het om agter die alternatiewe Griekse tranditerasie aan te sê. Dit beteken „gesalfde" en word van die koning van oud-Israel gebruik. Hiervan getuig veral die koningspsalms ${ }^{1}$ maar ook talle verwysings in die historiese boeke ${ }^{2}$. Ook ander funksionarisse is gesalf, soos hoëpriesters en priesters ${ }^{3}$ en ook profete 4 , maar alleen uit die koningsalwing het 'n hele teologiese kompleks ontwikkel. Daarom word in die Ou-Testamentiese wetenskap alleen t.o.v. die koningsalwing van 'n messiaanse teologie gepraat.

In die ou Ooste was die idee van 'n besondere band tussen die koning en die godheid algemeen bekend en meermale word die koning die seun van die god genoem. Vanweë die feit dat Israel in hierdie kultuurkring ingebed was, sou dit eienaardig gewees het as die Israelitiese konings nie ook sulke aansprake gemaak het nie ${ }^{5}$. Hierdie aanspraak word inderdaad gemaak, soos ons veral in die bekende Ps. 2 kan sien. Die gesalfde koning is die seun van God, maar anders as bv. in Egipte - geld hy nie as die fisieke 
seun van Yahweh nie, maar as sy aangenome seun. Hiermee is reeds ' $n$ belangrike waarneming gemaak: Die messiasidee in die Ou Testament is polities van aard en daarin eenstemmig met die Egiptiese en Mesopotamiese opvattings oor die seun van die godheid.

Sommige geleerdes, veral Skandinawiërs, beklemtoon verdere gemeenskaplikhede tussen die Ou-Testamentiese koningsteologie en die „koningsideologie" van die omliggende volke ${ }^{\circ}$. Byvoorbeeld: Die koning is 'n opvolger van die ou Kanaänitiese priesterkoning (Ps. 110); hy is verantwoordelik vir vrede, vrugbaarheid en geregtigheid (Ps. 72), sy troon sal vir ewig bly staan (Pss. 45, 132), en hy het die goddelike gesag agter hom (Ps. 2). Hiermee kom Babiloniese, Assiriese en Ugaritiese tekste grootliks ooreen ?. Vervolgens ontwikkel hierdie geleerdes op sulke gronde hul teorie dat die Christusverwagtinge van die Ou Testament hieruit gegroei het. Israel sou sy verwagting op die toekoms gerig het uit teleurstelling omdat die voorspoed wat deur die kultus (met sy koningspalms en al) gegenereer moes word, nie verwerklik is nie ${ }^{8}$. Die koning het 'n sentrale plek in die eskatologiese verwagting gekry omdat hy 'n sentrale plek in die kultus gehad het, en so ontstaan die eskatologiese messiasverwagting.

Hoewel daar duidelike verwantskap tussen talle aspekte van die Israelitiese koningskap en die van die omliggende volkere was, is dit te betwyfel dat die ooreenkomste so ' $n$ patroonmatige eenheid uitgemaak het dat ons van 'n ideologie kan praat. Daar is ook groot verskille tussen Israel en sy bure, en boonop is daar leemtes in ons kennis, sodat dit nie gerade is om teleurstelling met kultiese verwagtings as die oorsprong van die Christusverwagting te beskou nie. Dit lyk my meer aanneemlik dat die Israelitiese verwagtings van ' $n$ ideale messias in 'n politieke teologie as in 'n kultiese teologie ontstaan het. Aan die een kant het die Natansbelofte (1 Sam. 7) van 'n permanente troon vir die Dawidiese dinastie, en die gereelde besing van die koning se politieke deugde (geregtigheid, vrede, ens.) in die koningspsalms tot 'n onvoorwaardelike heilsteologie gelei. Dit is die God-is-aan-ons-kant-teologie waarteen Jeremia (bv. 6:14, 7:4, 8:11) en sy voorgangers (bv. Am. $5: 20$ ) hulle so heftig verset het. Solank die tempel staan en die kultus voortgaan, is alles in orde en is Jerusalem oninneembaar. Aan die ander kant begin die deuteronomiese teologie met 'n duidelike kritiek op die beleid van Salomo (Dt. 17:14-20) en word dié kritiek al hoe duideliker in die oordele van die deuteronomistiese geskiedwerk oor konings wat hul beleid nie skoel op Gods wil nie, en in die oordeelsprediking op sedelike grondslag van die vooreksiliese profete. So ontstaan daar 'n geweldige spanning: Die koningskap móét bly bestaan (Natan, koningspsalms); die koningskap kan nié bly bestaan nie (oordeelsprediking). En hieruit ontstaan die verwagting van 'n toekomstige Dawidiese messias wat die vervalle hut van Dawid weer sou oprig en 'n ideale vors sou wees. Die messiasverwagting is dus nie alleen 'n saak van 'n paar ,proeftekste" nie, maar 'n omvangryke aangeleentheid waarvan die wortels lê in die beoordeling van die koningsgeskiedenis aan die hand van 
Gods wil en waarvan die neerslag dus in groot dele van die Ou Testament voorkom.

' $n$ Interessante bevestiging hiervan is by die profeet Jesaja te sien. Hy gaan ook uit van die Jerusalemse teologie ('n ander naam vir die heilsteologie waarvan ons pas gepraat het), met dié verskil dat hy die heil nie onvoorwaardelik maak nie, maar afhanklik van die voorwaarde van geloofsvertroue (Jes. 7). M.a.w. vir Jesaja is die messiaanse afstamming van die koning en die daarmee gepaard gaande kultiese affirmasie nie genoeg nie; daarteenoor staan 'n ander pool.

Ná die ballingskap word die messiaanse verwagting al hoe sterker. Die katastrofe het immers die een pool van die spanning laat verdwyn - die goddelose messiaanse staat wat nie kòn bestaan nie het inderdaad verdwyn. Nou bly daar gevolglik alleen ruimte oor vir die ontwikkeling van die ander pool, nl. die betroubaarheid van die Natansbelofte. Oor die na-eksiliese profete (bv. Sag. $9: 9 \mathrm{vv}$.) heen tot in die apokaliptiek vind hierdie ontwikkeling plaas om in die boek Daniël en die magdom apokaliptiese werke van die tussentestamentêre tyd sy hoogbloei te bereik.

Volgens hierdie messiasverwagting sal daar 'n plotselinge wending kom wanneer die bose huidige bedeling vervang word deur die toekomstige bedeling waarin die lig die oorwinning oor die duisternis sal behaal. Die deurbraak beteken dat die ryk van die messias gevestig word. Op hierdie punt bevind die dissipels van Jesus hulle wanneer hulle wil weet of $\mathrm{Hy}$, in hierdie dae weer die koninkryk vir Israel gaan oprig".

Die apokaliptiese ontwikkeling van die messiasverwagting het ook ' $\mathrm{n}$ ander voorstelling in hom opgeneem. Die voorstelling van die menseseun (Dan. 7) kom ook in verskeie tussentestamentêre tekste voor ${ }^{\theta}$. Wat ookal die oorsprong van hierdie motief, dit word in die Joodse literatuur as 'n messiaanse titel gebruik. Daarom kon Jesus sy messiasskap daarmee aandui eerder as met die Aramese woord mesiha (Hebreeus mesiah). Lg. bekende term het nl. van oudsher af sy politieke konnotasie saamgedra, terwyl die titel baránäs̄ā (,mensseun") daarvan vry was en daarom aan Jesus die geleentheid gebied het om gevaarlike politieke byklanke te vermy.

'n Laaste aspek van die ontwikkeling in die messiasverwagting is omstrede. Dit gaan oor die Kneg van Yahweh wat ons in die tweede deel van die boek Jesaja ontmoet. Is hy 'n messiasfiguur? Volgens sommiges ${ }^{10}$ wel. Daar word geredeneer dat hy verbind kan word met die Babiloniese gebruik dat die koning boete doen en plaasvervangend vir sy volk ly. Andere ${ }^{11}$ meen dat hierdie verbinding met die oudoosterse ,koningsideologie" onhoudbaar is m.i. tereg omdat die Kneg nie politieke trekke vertoon nie. Messiaans kan hy ook nie wees nie omdat hy nie voorgestel word as 'n nakomeling van Dawid nie.

Hiermee is ' $n$ baie sketsmatige beeld gegee van die ontwikkeling van die Christusidee vanaf sy begin tot by Jesus. Wanneer Christene egter vra na die teologiese gehalte van die Ou-Testamentiese Christusprediking, is so 'n tradisiehistoriese beskrywing van 
hoe Israel deur die tyd heen die Christusvoorstelling beleef het, nie voldoende nie. Ons is egter, dink ek, nou georiënteerd genoeg om dieper te delf.

Die vraag wat nou gestel moet word, is of ons wel Christusprediking in die Ou Testament vind. Die antwoord hierop moet na my mening bevestigend wees. Dit bring ons dadelik by die volgende vraag: Waarin lê die Christusprediking van die Ou Testament? Hoe werk die Christusprediking daarvan?

Een manier om hierdie vraag te beantwoord, sou kon wees dat mens die Christus- of messiaanse tema of 'n aspek daarvan neem en aantoon hoe dit volgens die Nuwe Testament met Jesus Christus verband hou. Byvoorbeeld: Ons sou die salwing of die funksies of die Dawidiese afstamming of die Godseunskap van die oud-Israelitiese koning kon neem en aantoon dat dit verband hou met die salwing (christos), funksies, Dawidiese stamboom en Godseunskap van Jesus. Ons sou dan moes sê dat hierdie aspekte van die oud-Israelitiese koningskap iets onvolkome was en 'n voorafskaduwing van wat later sou kom. M.a.w. ons sou moes stel dat die betekenis van die skaduwee alleen vanuit die Nuwe Testament te sien is.

Alternatiewelik sou ons kon kies om gedeeltes van die Nuwe Testament te versamel waar daar gebruik gemaak word van die Ou-Testamentiese koningskapsmotief en daarvandaan terug kon redeneer. Byvoorbeeld waar van Jesus as die Seun van Dawid sprake is, waar Hy as Koning van die Jode voorgestel word, of waar spesifieke messiaanse tekste uit die Ou Testament op Hom toegepas word (soos Pss. 2 en 110 wat in Heb. 1 gebruik word). So 'n werkswyse sou weer by die onvolkomenheid van die Ou Testament uitkom, want dit sou nodig wees om vol te hou dat ons eers in die Nuwe Testament verneem wat die ware sin van hierdie OuTestamentiese gedeeltes is.

Derdens sou ons selfs die hele messiastema as Bybelse gedagte kon ignoreer en van 'n ander Nuwe-Testamentiese tema of op die pas aangeduide manier kon terugredeneer. Byvoorbeeld: Ons sou van Heb. 9 af terug kon redeneer en sê dat die ware betekenis van die talle offerwette in Levitikus en elders in die Pentateuch daar voorkom. Of ons sou kon uitgaan van die hoëpriesteridee in Heb. 7 en kon stel dat die Ou-Testamentiese hoëpriester eers hier "vervul" word, m.a.w. dat die hoëpriesterlike instelling 'n tipe van Christus is waarvan die sin in die afgebeelde en nie die afbeelding nie, lê.

Hierdie metodes mag miskien met die eerste oogopslag na aantreklik en selfs aangewese maniere lyk om die Ou-Testamentiese Christusprediking te verdiskonteer. Ek meen egter dat hulle meer probleme skep as oplos en die betekenis van die Ou Testament só verskraal dat geen reg aan hierdie groot versameling van boeke geskied nie. Kom ons kyk 'n bietjie van nader toe.

Die eerste beswaar is dat die gesketsde metodes almal met 'n Christologiese openbaringsmodel of, as $\mathrm{u}$ wil, verstaansleutel werk. Let wel dat ek nie praat van 'n Christosentriese prediking nie (daaroor meer aan die einde van die referaat), maar van 'n model 
waarvolgens die selfbekendmaking van God geskematiseer word ter wille daarvan dat die Christusprediking van die $\mathrm{Ou}$ Testament aanskoulik gemaak word. So 'n model werk met 'n innerlike weerspreking: Om enigsins sinvol te wees, moet hierdie model volhou dat Christus die enigste ware openbaring van God is. Daarom moet $\mathrm{Hy}$, sy dit op mistieke wyse, oral in die Ou Testament skuil anders is die Ou Testament nie voluit openbaring nie. Die blote feit egter dat Christus die enigste ware openbaring van God sou wees, beteken dat Gods openbaring nie in die Ou Testament kan wees nie. As, alternatiewelik, hierteen aangevoer sou word dat Christus nie die enigste ware openbaring van God is nie maar slegs die finale of die hoogste vorm daarvan, dan verval die aktualiteit en innerlike bedoeling van die Christologiese model buitendien, want dan is dit moontlik dat Gods openbaring in die Ou Testament kan wees sonder dat Christus daarin hoef te skuil om die Christelike sin daarvan te verleen.

Die tweede beswaar is dat al drie werkswyses ' $n$ soort tekstipo. logie inhou. D.w.s. daar word na Nuwe-Testamentiese teenhangers gesoek vir Ou-Testamentiese gedeeltes terwyl die Oue sy sin dan slegs in die Nuwe vind en daarom 'n tipe van die Nuwe is. Ten spyte van die oënskynlike aantreklikheid hiervan kan dit nie werk nie. Die prinsipe waarmee so 'n tegniek werk, is dat die Ou Testament alleen sin maak vir sover daar teenhangers van sy woorde in die Nuwe Testament voorkom. Hierdie teenhangers moet dan funksioneer as direkte vervullers van die onvolkome en skaduagtige „,heenwysings" in die Ou Testament. Vereers is daar 'n bloot fisiese rede waarom so 'n veronderstelling onhoudbaar is. Dit is dat die Ou Testament drie maal so dik as die Nuwe is en dat daar eenvoudig honderde motiewe en temas in die Ou Testament voorkom wat nie 'n teenhanger in die Nuwe Testament het nie. Waarom sou die metode dan vir sommige temas geldig wees en nie vir andere nie? So 'n eklektisisme kan nie deel uitmaak van 'n metode wat as 'n prinsipiële ontsluitingsmeganisme bedoel is nie, want die oomblik as die beginsel deurbreek word, val die hele werkswyse in duie.

Verder is daar 'n diepliggende teologiese beswaar. Hierdie hele model is gebou op die veronderstelling dat die Ou Testament ' $n$ mislukking is. Dit sou ons bring op die standpunt van Rudolf Bultmann ${ }^{12}$ dat God self sy volk Israel op 'n weg van mislukking (,Scheitern") gelei het. Wanneer dit is hoe die skema van belofte en vervulling voorgestel word, lyk dit my onmoontlik om te handhaaf. Daar is natuurlik beloftes en voorspellings in die Ou Testament, maar hier word die geheel as 'n belofte geinterpreteer op grond van die idee dat God sy volk die mislukking ingelei het. Dit is voorwaar 'n negatiewe soort belofte en daarom ook 'n eienaardige soort vervulling - eerder 'n herstel van 'n fout. Later sal ek stel hoe ons na my mening wèl van belofte en vervulling kan praat.

'n Variasie van hierdie beswaar is dat die Ou Testament oor- 
bodig is. As hy alleen sin maak in terme van die Nuwe Testament, het ons alleen die Nuwe nodig omdat dié alleen tog die volle waarheid bevat. Die Ou Testament sou dan hoogstens 'n tipe historiese toeligtingswaarde hê - ongeveer soos die oudoosterse tekste waartoe die argeologie ons toegang verleen het.

'n Derde onhoudbaarheid van die metodes waarna ek verwys het, is dat al drie die historiese karakter van die Ou Testament misken. As die sin van die Ou Testament eers met die koms van Christus sigbaar geword het, beteken dit vanself dat die sin daarvan nie voбr sy koms sigbaar was nie. Wanneer so 'n uitspraak van woorde gemaak word waarvan die pretensie is dat hulle maklik verstaanbaar is (Deut. 30:11-14), dan word gesê dat dié woorde sinneloos was, want woorde se funksie is om sin oor te dra. Had Gods woorde op 'n bepaalde stadium geen ware sin nie, dan is dit moeilik om te sien hoe dit openbaring kan heet. Wil ons van sy woorde as openbarende selfbekendmaking praat, sal ons moet aandring daarop dat hulle ten volle sin gemaak het voor Christus verskyn het. Doen ons dit nie en probeer ons uit die dilemma kom deur te sê dat daar wel volle sin in die woorde was maar dat hulle dié sin net nie laat blyk het nie, dan gebruik ons 'n sofisme omdat woorde se sin daarin bestaan dat hulle kommunikasie bewerkstellig. En doen ons dit wel, dan verval die aktualiteit van die Christologiese model weer eens, want dan is dit nie nodig om die sin van Ou-Testamentiese woorde te red deur te stel dat die Christusprediking daarvan in 'n Christologiese model geleë is nie.

Ten slotte lê daar nòg ' $n$ onoorkomelike moeilikheid in die „vooruitwys"-beskouing. Daar sal alleen waarlik van 'n reeks vingerwysings of voorafskaduwings in die Ou Testament gepraat kan word as elke heenwysing deur die betrokke outeur bedoel en bewustelik verwoord is. Dit het die vader van die tipologie, Theodorus van Mopsuestia (oorl. 429), al ingesien toe hy teenoor die Alexandrynse allegoriese uitleggers volgehou het dat 'n tipologiese vooruitwysing alleen houdbaar is as die profeet self daarvan bewus is ${ }^{13}$. Terloops kan ons opmerk dat hierdie soort tipologie nog aanspraak kan maak op 'n aanvaarbare begrip van wat "tipe" beteken; daarteenoor is daar weinig onderskeid tussen die soort tipologie wat hierbo gekritiseer is en allegoriese praktyke. Wanneer mens afsien van Theodorus se vereiste van profetiese bewussyn, word jy gedwing tot die psigologiese vernedering van 'n erkenning van skuld aan allegoriese praktyke. Maar iets ergers sal ook toegegee moet word, nl. dat die eksegeet die huldiger van ' $n$ meganiese inspirasie-opvatting is. Want as die woorde se wat die outeur nie bedoel nie, is die outeurs bloot die willose penne of - om modern te wees - tikmasjiene van die Heilige Gees. Ons weet almal dat geen ernstige teoloog sedert die demise van die ortodoksie so 'n siening meer volhou nie. Nou is dit aantoonbaar dat die oorgrote meerderheid van die Ou-Testamentiese tekste nie bedoel het wat later in Christus gebeur het nie. Byvoorbeeld: Wanneer daar van die Judese koning gesing of vir hom gebid word (bv. Pss. 110, 20), dan dek dit ewe min die bedoeling 
van die evangelies as wat die beskrywing van die binne- en buitelandse betrekkinge van die koning in Ps. 72 dit doen. Hiervoor hoef eintlik nie voorbeelde aangebied te word nie, want die innerlike logika van die ,voorafskaduwing"-teorie vereis juis dat die Ou-Testamentiese bedoeling nie die Nuwe-Testamentiese moet dek nie. Waarom anders sou dit 'n ònvolkome skadu wees van die volheid wat later sou kom? Selfs al sou die antwoord lui dat slegs die eksplisiet voorspellende gedeeltes ter sake is, bly die beswaar nog vir die grootste deel van die Bybel staan.

Tot dusver het ek betoog dat die Christusprediking van die Ou Testament nie uitgewys kan word deur 'n Christologiese model te volg met tipologiese, a-historiese en meganiese aspekte nie. Aangesien dit wat ek afgewys het die Ou Testament in die lig van die Nuwe lees, is die logiese vraag wat ek moet beantwoord of daar dan wel ' $n$ ander manier is om die lig van die Nuwe Testament oor die Oue te laat val. M.a.w.: is daar 'n manier om dieselfde doel te bereik en tegelykertyd die swakhede van die Christologiese model te vermy? $\mathrm{Na}$ my mening kan dit wel gedoen word. Ons kan reg laat geskied aan die konsep van vervulling van die $\mathrm{Ou}$ Testament deur Christus sonder om ons prys te gee aan die onhoudbaarhede waarvan hierbo sprake was. Hierdie positiewe kant sal nou die res van my betoog uitmaak.

Gegewe dat ons die Ou Testament kan lees en in sy konteks kan verstaan, is die eerste stap 'n geloofsbelydenis. Die God van Abraham, Isak en Jakob, die God van die Ou Testament, is dieselfde as die Vader van Jesus Christus en God van die Nuwe Testament. Dit kan nie rasioneel bewys of uitgeredeneer word nie - dit is 'n saak van geloof ${ }^{14}$. Nou: As ons met dieselfde God te doen het wat sy Seun in die volheid van die tyd gestuur het ${ }^{15}$, dan beteken dit dat daar kontinuïteit tussen die $\mathrm{Ou}$ en die Nuwe Testament bestaan. Want die handelinge waarvan die Ou Testament getuig, gaan voort in dié waarvan die Nuwe Testament getuig. Daarom het ons die volle reg om te praat van Gods doel met sy volk Israel deur die geskiedenis heen tot by sy Seun Jesus Christus.

Die tweede oorweging is om aandag te skenk aan die innerlike struktuur van hierdie doel. Waaruit is dit saamgestel en hoe werk dit? Uiteraard is die enigste plek waar ons hieroor kan navraag doen, die Ou Testament. Neem ons, soos elke verantwoordelike eksegeet behoort te doen, die historiese konteks in ag, dan vind ons ' $n$ legio van motiewe en tema's, bedoelings en intensies by talle wetgewers, vertellers, digters, priesters, profete en wyse manne. Bestudeer ons die resultate van so 'n ondersoek sistematies, dan vind ons ' $n$ hele godsdiens met talle aspekte wat met die tyd 'n aanmerklike ontwikkeling deurgegaan het. Die hele religieuse korpus is keer op keer geherinterpreteer - in die tyd van die $\mathrm{Ou}$ Testament self en daarna deur die tussentestamentêre periode heen tot by Jesus. In hierdie ryke veelvoud le die innerlike struktuur van Gods doel met Israel - hoewel ons natuurlik moet onthou dat ons alleen maar flitse van sy raad kan onderken. Dit alles beteken 
dat Gods doel nie geleë is in kriptiese woorde en gebruike waarvan die draers niks geweet het en dus die lewelose kassetbande was nie. Die offers was daar om in hul aktuele situasie versoening te bewerkstellig tussen 'n waarlik teenwoordige God en 'n werklik sondige volk. Die himnes was daar vir mense wat werklik gejubel het en hul lof aan God betekenisvol gebring het. Die koningsliedere was daar om die werklike Judese koning toe te sing en Gods seën oor hom af te bid. Die sosiale kritiek van die profete was daar om die werklike misstande van die tyd op betekenisvolle wyse te ontbloot. En so kan ons aangaan. Die vraag waardeur Gods doel met sy volk geopereer het, moet dan soos volg beantwoord word: Deur die hele godsdienstige oorlewering van ou Israel en nie alleen deur die messiaanse tradisie wat alleen in sekere sektore van daardie oorlewering voorkom nie.

En nou die vraag hóé dit werk. Die belydenis dat die God van die Ou Testament ook die Vader van Jesus Christus is, beteken dat $\mathrm{Hy}$ in die geskiedenis en godsdiens van Israel heengewerk het na die koms van sy Seun. Die inspirasie beteken dan nie die meganiese voortstu van skrywerspenne nie, maar die leidende teenwoordigheid van God in die vorming van die hele tradisie. Dan is dit geen wonder dat die Seun van hierdie God sy eie roeping en taak vertolk in terme van hierdie tradisie nie. Dan is dit ook nie verbasend nie dat diegene wat later aangaande hierdie dinge getuig het, die werk van hul Heer eweneens in terme van die veelstaltige Ou-Testamentiese tradisie geinterpreteer het. Daarvoor gebruik hulle nie net die messiaanse aspek nie, maar talle ander: skepping, aartsvaders, eksodus, wetgewing, woestynreis, intog, kultus, profete, liriek en selfs motiewe wat in die oud-Christelike kanon verwoord word maar nie in die Hebreeuse kanon nie ${ }^{16}$. En dan is die modus van die inspirasie van die Nuwe-Testamentiese getuies dieselfde as dié van die Ou-Testamentiese getuies, nl. die leidende teenwoordigheid van God in die vorming van die vroeg-Christelike tradisie.

Hierdie hele beweging na Christus beteken dat die Ou-Testamentiese tradisie op ' $n$ bepaalde stadium vol geword het, of - soos ons sê - vervul is in die volheid van die tyd. Daarom was Jesus en sy volgelinge gedrenk in die religieuse tradisie van Israel. En dit gooi 'n verhelderende lig op die vleeswording van die Woord: $\mathrm{Hy}$ het nie alleen in vae terme 'n mens geword nie, maar spesifiek 'n tiplese Jood van die eerste eeu. Hy is besny, het die sinagoge besoek, die heilige skrifte gelees en uitgelê, die rabbynse tora geken en gediskusseer, en Hy het ,van Moses en al die profete af" die dinge wat op Hom betrekking het, uitgelê. Soos die liggaam van Maria die fisiese matrix was waarin Christus mens geword het, so het die ganse Ou-Testamentiese tradisie die geestelike matrix van sy menslike lewe uitgemaak. Hiersonder is sy werk nie voorstelbaar nie. Die kumulatiewe tradisie van die Ou Testament het dit dus moontlik gemaak vir die werk van Christus om te wees wat dit was. Dit kon alleen vertolk en geproklameer word in terme van die verwagtinge en godsdienstige kategorieë wat deur die Ou-Testamentiese tradisie na die Jodendom van die eerste eeu deurgegee is. Die 
Christusprediking van die Ou Testament is dan iets wat vooruit werk vanaf die oue na die nuwe in historiese volgorde. Dit is dus nie 'n saak van een tema of 'n groep motiewe of aspekte of tekste nie, maar 'n funksionele saak.

Dieselfde funksionele muntstuk het ook 'n ander kant. Netsoos die Ou Testament die basis verskaf het vir Jesus en sy volgelinge om sy werk te vertolk, so het dit ook die basis verskaf vir sy teenstanders om hul verwerping mee te motiveer. So is die werking van die $\mathrm{Ou}$ Testament in negatiewe opsig ók die grond waarop die veroordeling van Jesus geplaas is. Hierdie werking van die OuTestamentiese tradisie het net soveel bygedra tot die volbrenging van die verlossingswerk van Christus, want - om Hom self aan te haal - „móés die Christus nie hierdie dinge ly en in sy heerlikheid ingaan nie?" (Luk. $24: 26$ ). Kom ons illustreer dit met 'n aangewese voorbeeld $\mathrm{nl}$. die gebruik van die messiasverwagting. In die eerste eeu was die eeueoue politieke komponent van die messiasidee prominent, selfs by die dissipels wat wou hê dat Jesus ,in hierdie dae die koninkryk vir Israel weer oprig". Aan die een kant omlyn Jesus sy taak deur die titel "messias" en daarmee saam dus die politieke konnotasie te vermy (dit is sý interpretasie in terme van die tradisie). Aan die ander kant gee dit juis aanstoot vir mense wat vanweë hul deurwintering in die Ou-Testamentiese tradisie voor die Jodendom aan 'n lydende messias niks het nie (dit is hùl interpretasie in terme van dieselfde religieuse kompleks). Beide Ou-Testamenties gebaseerde vertolkings lei tot sy kruisdood en ons verlossing. Weer sien ons dat die Ou Testament funksioneel betrokke is by die heilswerk van Christus. Die ganse Ou Testament werk in positiewe èn negatiewe opsigte na Christus toe.

Maar as die $\mathrm{Ou}$ Testament so 'n vooruitwerkende funksie het, is daarmee ook die grond gegee vir die moontlikheid om vanuit die eindpunt terug te kyk na die voorstadia van die Christusgebeure. Die volgelinge van Jesus het die Ou Testament gehanteer as mense wat reeds in Hom as die Christus geglo het. Dit is waar dat die Ou Testament aan hulle die verwysingsraamwerk gegee het om Hom as die messias en nie 'n boeddha of voorvadergees nie te glo. Maar dit wil nie sê dat hulle in Hom en niemand anders geglo het op grond van die Ou Testament nie. Die ander Jode het ook ' $n$ messiasverwagting gehad maar nie aanvaar dat Jesus van Nasaret die Koning van die Jode is nie. M.a.w. die eiesoortige verband wat die Nuwe Testament terugwerkend met die Oue lê, hang nie af van 'n bepaalde uitleg van die Ou Testament nie dié is dieselfde as die gangbare Joodse uitleg soos te sien by die rabbyne en veral die targums. Dit hang wel af van ' $n$ bepaalde geloofsoortuiging, $\mathrm{nl}$. dat niemand anders die Christus is as hierdie bepaalde Galileër nie. Hulle het dan die gewone onwetenskaplike vertolkingstegnieke van hul tyd gebruik omdat dit 'n nuttige manier was om Hom aan die mense van destyds te verkondig en nie omdat dit 'n dwingende bewys van die identiteit van Jesus was nie. Daarom kan ons nie sommer die Nuwe-Testamentiese interpretasie van OuTestamentiese tekste as korrekte weergawes van die betekenis van die betrokke passasies aanvaar nie. Ons uitleg van die Ou Testament 
en ons uitleg van die Nuwe-Testamentiese gebruik van die $\mathrm{Ou}$ Testament is twee verskillende dinge. As Mat. 1:23 na Jes. $7: 14$ verwys om die maagdelike geboorte te verkondig, beteken calmã in Jesaja nog steeds nie „maagd" nie en gaan dit daar ook nie om die verwagting van die ideale messias nie maar nog steeds om die ambivalente teken van heil en onheil in die Siro-Efraimitiese oorlog. Maar op grond van sy eie geloofwaardigheid kan ons ook glo dat Matteuis gelyk het met sy proklamasie van die maagdelike geboorte.

So is daar 'n dialektiese verhouding tussen die twee testamente. Eers ' $n$ beweging vorentoe en op grond daarvan terug. Ter wille van duidelikheid en die vermyding van verwarring, verkies ek dat ons eerder praat van „die lig van die Christusgebeure oor die Ou Testament laat val" as van ,die Ou Testament in die lig van die Nuwe lees". Of, as ons dan lg. uitdrukking wil gebruik, moet ons hom duidelik omskryf. Dit beteken nie dat ons die duidelik vasstelbare betekenis van die Ou-Testamentiese woorde gaan vervang met 'n sg. „ware" betekenis wat ons vanuit die Nuwe Testament indra nie, maar dat ons die skopus van elke Ou-Testamentiese teks in die perspektief van die Christusgebeure beoordeel.

Spreek Ps. 72 bv. van geregtigheid wat die koning aan sy onderdane verskuldig is, dan is dit nie ' $n$ verskuilde heenwysing na Christus omdat die Nuwe Testament Hom as die Seun van Dawid beskou nie. Die Christusperspektief maak egter wel dat ons aan elke politieke maghebber die eis van geregtigheid moet stel. Hoekom? - Omdat ons as Christusgelowiges ons in relasie stel tot die klassieke model waaruit ons onder die leiding van die Heilige Gees vasstel wat God van ons wil. Spreek Deuterojesaja van 'n herstel van Jerusalem, is dit nie ' $n$ verskuilde en onbedoelde heenwysing na die hemelse Jerusalem nie, maar na die Palestynse stad wat inderdaad in Esra en Nehemia se tyd herstel is. Die profesie spreek ons egter aan omdat ons stroomop kyk. Ons glo in dieselfde God vir wie ons verlossing uit ons nood belangrik is, en dit is dieselfde verlossing wat van Deuterojesaja se tyd stroomaf tot by ons gekom het. So werk die Ou Testament, of beter: die God van die $\mathrm{Ou}$ Testament, deur die tyd heen. En omdat sy werk in Jesus Christus gesentreer is, werk die Ou Testament Christuspredikend of ons nou met die messiaskonsep daarin te doen het of nie.

Kyk ons nou terug oor hierdie betoog, dan sien ons dat dit voluit moontlik is om van belofte en vervulling te praat sonder om daarvan 'n hermeneutiese sleutel te maak. Belofte waar daar beloftes en voorsegginge voorkom in die eskatologiese perikope. En vervulling in die sin van die bereiking van Gods doel met die verskillende strata van die $\mathrm{Ou}$ Testament. Hierdie ryke verskeidenheid is te pluriform om onder 'n enkelvoudige noemer soos belofte-vervulling of wet-evangelie geskematiseer te word. Boweal kan ons eerder 'n Trinitariese benadering tot die $\mathrm{Ou}$ Testament daarop nahou ${ }^{17}$ as 'n kunsmatige Christologiese verstaansmodel. Want deur rekening te hou met die doel van die Vader met sy Seun en deur van die leiding van die tradisie deur God as inspirasie te spreek, mak ons erns met die werk van Vader, Seun en Gees. Die resultaat hiervan is Christosentriese teologie en prediking - iets totaal anders 
as 'n verstaansmodel. En teologiese arbeid aan die Ou Testament wat met hierdie toespitsing te doen het, het vanuit sy binneste aard te doen met die Christusprediking van die Ou Testament.

Voordrag gelewer voor G.T.V., Pretoria, Maart 1981.

\section{VOETNOTAS}

1 Soos Pss. 2, 18, 20, 21, 44, 45, 72, 89, 101, 110, 132, 144.

2 Daar is $38 \times$ sprake van; vgl. J. A. Soggin, s.v. melek, THAT I, 913

3 Resp Ex. 29:4-9, Lev. $4: 3$ vv. en Ex. $28: 41,3: 30-$ benewens andere.

41 Kon. $19: 16$.

5 H. Ringgren, The Messiah in the Old Testament, Londen 1967, p. 12.

B Bv. I. Engnell, Studies in divine kingship in the Ancicnt Near East, Oxford 1967 en H. Ringgren, a.w.

7 Engnell, a.w., hoofstukke 4, 5; Ringgren, a.w. p. 20-21.

8 S Mowinckel, Psalmenstudien II, Oslo 1921, deel 2.

9 Mowinckel, He that cometh, Oxford 1959, p. 360-362.

10 Bv. Ringgren, a.w., p. 65-67.

11 Bv. Mowinckel, He that cometh, p. 221-232.

12 "Weissagung und Erfullung", in Glauben und Verstehen, Tubingen 1952, p. $184-185$.

13 J. J. Kiwiet, „Hermeneutics in Historical Perspective", Southwestern Journal of Theology 16/2 (1974), p. 3-4.

14 Dit is vir my onbegryplik hoe F $N$. Llon-Cachet, Die Kerkblad, 2-7-1980, p. 1, daarby uitkom dat ek as vertrekpunt die ,kritiese wetenskap wat koudbloedig wil ontleed en sy ele resultate as die alleen gesagvolle wil aandien" sou huldig met die doel om in die Bybel „agter die oënskynlike boodskap die waarheid te ontdek'.

15 'n Uitdrukking wat James Barr, Old and New in Interpretation, London 1966 p. 153, in 'n soortgelyke konteks as die huidige gebruik.

161 Kor. $2: 9$ (Jes. 64:4, 52:15, Sirag 1:10); Jud. vs. 14-15 (Ass. Mosis, Ass. Henoch); vgl. Jud. vss. 7, 9, 11, 14, Mat. $27: 9$, Luk. 11:49, Joh $7: 38$ e.a. waar daar moontlik ook verwysings na apokriewe geskrifte voorkom.

17 Barr, a.w., p. 153-154. 